\title{
Experimental Study on the Permeability and Microstructure of Remoulded Silty Clay Corroded by Landfill Leachate
}

\author{
Chaofeng Wang*, Haijun $\mathrm{Lu}^{*}(* *) \dagger$, Dinggang $\mathrm{Li}^{*}$ and Jixiang $\mathrm{Li}^{*}$ \\ * School of Civil Engineering and Architecture, Wuhan Polytechnic University, Wuhan 430023, China \\ ** State Key Laboratory of Geomechanics and Geotechnical Engineering, Institute of Rock and Soil Mechanics, Chinese \\ Academy of Sciences, Wuhan 430071, China \\ $\dagger$ Corresponding authors: Haijun Lu; lhj@whpu.edu.cn
}

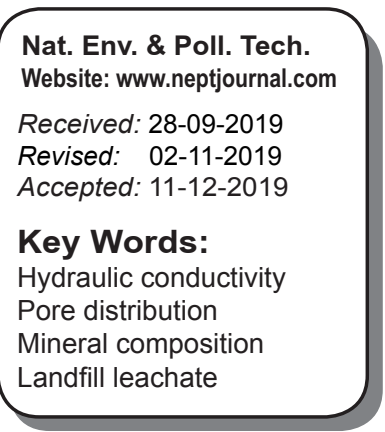

\begin{abstract}
This paper explores the macroscopic permeability characteristics, pore distribution, mineral composition, and microstructure changes in remoulded silty clay under different concentrations and different back pressures through flexible-wall triaxial permeability tests, nuclear magnetic resonance tests, X-ray diffraction tests, and scanning electron microscope tests. The results of the flexible-wall triaxial permeability tests indicate that the hydraulic conductivity of the landfill leachate with different concentrations increases to the peak value in $108-132 \mathrm{~h}$ period and then decreases to a stable value in 252-264 h period under the action of different back pressures. The nuclear magnetic resonance tests show that the pore distribution of the remoulded silty clay is macropore after it is corroded by the leachate. Increasing the concentration of landfill leachate and reducing the back pressures can reduce the overall development effect of pores. The X-ray diffraction tests show that the weakly acidic corrosive environment provided by remoulded silty clay and landfill leachate reduce respectively the contents of montmorillonite, muscovite, and illite by $33.52 \%, 23.57 \%$ and $63.51 \%$, while kaolinite and albite increase by $283.40 \%$ and $188.64 \%$. Finally, scanning electron microscope tests show that the corrosion of landfill leachate and the plugging of organic pollutants in the infiltration process reduce the apparent pore ratio of the microstructure of remoulded silty clay and the hydraulic conductivity gradually decreases.
\end{abstract}

\section{INTRODUCTION}

Currently, compacted clay is widely used as an impervious material for landfills in China. Its permeability is key, and it must comply with the requirements of the Chinese code which states that the hydraulic conductivity should not be greater than $1.0 \times 10^{-7} \mathrm{~cm} / \mathrm{s}$ (CJJ176-2012). The leachate produced by the landfill site has complex components, high dissolved concentrations of heavy metal ions and various other ions, and it contains aromatic hydrocarbons and other industrial organic compounds (Kjeldsen et al. 2002). When leakage occurs, the leachate corrodes the impermeable layer at the bottom of the landfill site, changes the microstructure of the clay layer at the bottom, destroys the stability of the impermeable layer, and can lead to serious pollution of surface water and groundwater.

In recent years, there have been numerous experimental explorations and theoretical results on the macroscopic characteristics and microstructure of clay. Some scholars explored the changes in the conventional parameters of pollutants and the relationship between the mechanical properties and the microstructure of compacted clay after the landfill leachate eroded, which can help evaluate the applicability of liner materials. The possibility of high concentration leachate blocking compacted clay was simulated. Combined with SEM photos, it is shown that the compacted clay has hydraulic blockage under leachate erosion (Li et al. 2013, Zhao et al. 2016, Met \& Akgün 2015, Zhan et al. 2017, Razakamanantsoa \& Djeran-Maigre 2016, Safari \& Valizadeh 2017). Researchers have investigated the effects of bentonite, lime, zeolite, and other materials as well as ion concentration and valence on clay permeability (Dontsova \& Norton 2015, Roth \& Pavan 1991, Zhou et al. 2015, Varank et al. 2011, $\mathrm{Li}$ et al. 2008). The permeability characteristics of original clay, recomposed clay and improved clay are explored, and a more suitable calculation expression for consolidation hydraulic conductivity of remoulded clay is calculated, which has important guiding significance for practical engineering (Gu et al. 2003). Although there have been many research works on the erosion of compacted clay using the landfill leachate, there are few studies on the relationship between the mineral composition, pore distribution, microstructure 
changes, and macroscopic permeability characteristics of the remoulded silty clay by landfill leachate corrosion; therefore, the correlation needs to be further explored.

To study the relationship between the macro permeability and microstructure of remoulded silty clay corroded by landfill leachate, this paper analyses the change of hydraulic conductivity curve of remoulded silty clay through flexible-wall triaxial permeability tests. Then, through nuclear magnetic resonance (NMR) tests, X-ray diffraction (XRD) tests, and scanning electron microscope (SEM) tests, pore distribution, mineral composition, and microstructure changes in the remoulded silty clay were respectively studied. Finally, the macro permeability characteristics and microstructure changes in remoulded silty clay corroded by landfill leachate were analysed to illustrate the relationship between them.

\section{MATERIALS AND METHODS}

\section{Materials}

The buried depth of the soil used for the test is about $2 \mathrm{~m}$, which is taken from a construction site in Huangpi District, Wuhan, China, and it is utilized for independent sealed storage. Its basic physical characteristics are provided in Table 1, and its basic chemical and mineral composition are listed in Table 2. Fresh landfill leachate used in the test was obtained from the Chenjiachong Landfill Site in Xinzhou District of Wuhan City, with a concentration of $100 \%$. Its basic physical and chemical characteristics are summarized in Table 3. $1 \mathrm{~L}$ and $5 \mathrm{~L}$ distilled water was added to each litre of fresh landfill leachate to prepare $50 \%$ and $16.7 \%$ landfill leachate for the tests.

\section{Methods}

Flexible-wall triaxial permeability tests: These tests are carried out according to the standard ASTM D5084-2010. The instrument adopts the PN3230M environmental geotechnical flexible wall permeameter (triple type) manufactured by GEOEQUIP. It adopts the cell pressure of $350 \mathrm{kPa}$, and back pressures of 100,200, and $300 \mathrm{kPa}$. The cylindrical soil sample with a diameter of $50 \mathrm{~mm}$ and a height of $100 \mathrm{~mm}$ is corroded by landfill leachate with concentrations of 100 $\%, 50 \%$, and $16.7 \%$, and the variation rule of the hydraulic conductivity of each layer is observed and obtained. According to the standards (ASTM D5084-2010, SL237-1999), the hydraulic conductivity is calculated by:

$$
K=\frac{Q L \rho}{10 A t \cdot \Delta P}
$$

Where, $k$ is the hydraulic conductivity, $\mathrm{cm} / \mathrm{s} ; Q$ is the amount of water seepage in penetration time $t, \mathrm{ml} ; L$ is the

Table 1: Basic physical characteristics of remoulded silty clay used in the tests.

\begin{tabular}{|lllllll|}
\hline $\begin{array}{l}\text { Optimum water } \\
\text { content }(\%)\end{array}$ & $\begin{array}{l}\text { Maximum dry density } \\
\left(\mathrm{g} \cdot \mathrm{cm}^{-3}\right)\end{array}$ & Liquid limit $(\%)$ & Plastic limit $(\%)$ & Plasticity index & Porosity ratio & Specific gravity $\left(\mathrm{g} \cdot \mathrm{cm}^{-3}\right)$ \\
\hline 18.5 & 1.71 & 34.4 & 18.8 & 15.6 & 0.36 & 2.65 \\
\hline
\end{tabular}

Table 2: Basic chemical and mineral composition of remoulded silty clay used in the tests.

\begin{tabular}{|c|c|c|c|c|c|c|c|c|}
\hline \multirow{2}{*}{$\mathrm{pH}$} & \multirow{2}{*}{ Soluble salt (\%) } & \multirow{2}{*}{ Organic matter $(\%)$} & \multicolumn{6}{|c|}{ Mineral composition (\%) } \\
\hline & & & Quartz & Montmorillonite & Kaolinite & Albite & Muscovite & Illite \\
\hline 5.5 & 0.6 & 1.8 & 23.41 & 20.94 & 4.76 & 6.69 & 21.09 & 23.10 \\
\hline
\end{tabular}

Table 3: Basic chemical characteristics of landfill leachate.

\begin{tabular}{|c|c|c|c|c|c|}
\hline Contaminants & Parameter values $\left(\mathrm{mg} \cdot \mathrm{L}^{-1}\right)$ & Determination method & Contaminants & Parameter values $\left(\mathrm{mg} \cdot \mathrm{L}^{-1}\right)$ & Determination method \\
\hline $\mathrm{pH}$ & 6.1 & GB/T 6920-86 & COD & 4107 & HJ/T 399-2007 \\
\hline DO & 3.7 & GB/T 7489-87 & TOC & 692.5 & HJ 501-2009 \\
\hline $\mathrm{N}-\mathrm{NO}_{3}$ & 16.57 & HJ/T 346-2007 & $\mathrm{SO}_{4}{ }^{2-}$ & 5.8 & GB/T 13196-91 \\
\hline $\mathrm{N}-\mathrm{NO}_{2}$ & 0.50 & HJ/T 197-2005 & $\mathrm{Cl}^{-}$ & 2022.9 & GB/T 11896-89 \\
\hline $\mathrm{N}-\mathrm{NH}^{4+}$ & 2779.9 & HJ 666-2013 & $\mathrm{Na}^{+}$ & 1855.6 & GB/T 11903.89 \\
\hline $\mathrm{P}-\mathrm{PO}_{4}$ & 21.2 & HJ 669-2013 & $\mathrm{Zn}$ & 276 & GB $7472-1987$ \\
\hline TP & 25.5 & HJ 671-2013 & $\mathrm{Cu}$ & 891 & HJ 485-2009 \\
\hline $\mathrm{BOD}_{5}$ & 1457.1 & HJ 505-2009 & $\mathrm{Ni}$ & 370 & GB 11912-1989 \\
\hline
\end{tabular}


height of the sample, $\mathrm{cm} ; \rho$ is the solution density, $\mathrm{g} / \mathrm{cm}^{3} ; A$ is the cross-sectional area of the sample, $\mathrm{cm}^{2}$; and $\Delta P$ is the backpressure, $\mathrm{kPa}$.

Nuclear magnetic resonance (NMR) tests: The NMR apparatus model was PQ-001 Mini NMR (Shanghai Niumai Electronic Technology Co. Ltd.). The magnetic field strength was $0.5 \pm 0.08 \mathrm{~T}$ and the operational test area was $60 \mathrm{~mm} \times$ $60 \mathrm{~mm}$. To generate a stable and uniform magnetic field, the temperature of the magnet unit was set to $32 \pm 0.01^{\circ} \mathrm{C}$, and a polytetrafluoroethylene ring cutter that has a diameter of 45 $\mathrm{mm}$ and a height of $20 \mathrm{~mm}$ was used for sample preparation. First, three layers of cylindrical soil samples were cut from the bottom to the top at 0-20 mm, 40-60 mm, and 80-100 $\mathrm{mm}$, respectively, after the flexible-wall triaxial permeability tests. Then, the central soil samples of each layer were collected by polytetrafluoroethylene ring cutters for NMR tests. Finally, the transverse relaxation time $T_{2}$ is provided by the Carr-Purcell-Meiboom-Gill (CPMG) sequence and the pore distribution of the remoulded silty clay is obtained.

$T_{2}$ can be expressed by the $T_{2}$ surface relaxivity $\rho_{2}, S / V$ that is the ratio of the pore surface area $S$ to the pore water volume $V$ and pore radius $R$ as:

$$
\frac{1}{T_{2}} \approx \rho_{2}\left(\frac{S}{V}\right)_{\text {pore }}=\rho_{2} \frac{2}{R}
$$

Further, Eq. (2) is simplified as:

$$
T_{2}=a \cdot R
$$

In the formula, the value of $a$ is a constant, which is 2.25 $\mathrm{ms} / \mu \mathrm{m}$. According to Eq. (3), pore distribution can be set up according to the $T_{2}$ distribution curves (Tian et al. 2013, Li et al. 2008).

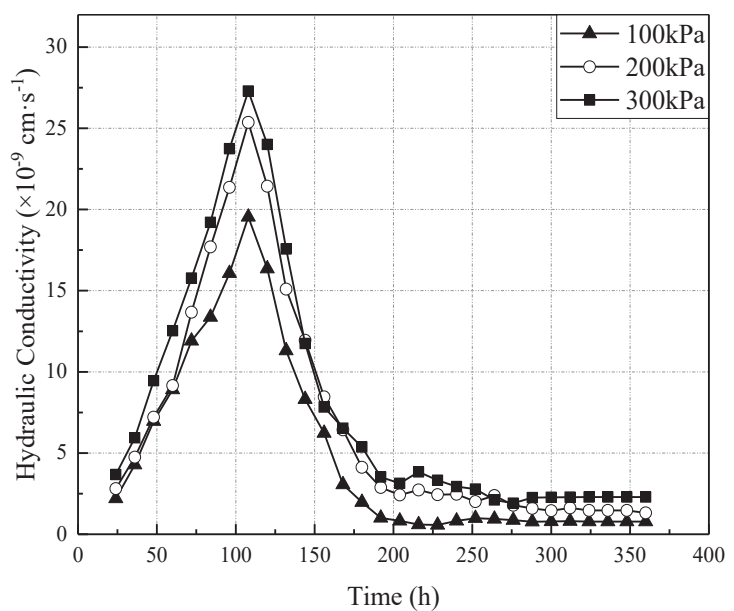

Fig. 1: Hydraulic conductivity curves of $100 \%$ landfill leachate corrode remoulded silty clay under different back pressures.
X-ray diffraction (XRD) tests: According to the Chinese code (SY/T 5163-2010), under the condition of $50^{\circ} \mathrm{C}$, the lower soil samples $(0-20 \mathrm{~mm})$ with various concentrations of corrosion are dried to constant quality and then ground into powder by mortar. After passing through a 200-mesh sieve, the samples are diffracted by an X-ray diffractometer with the model of EMPYREAN at a speed of $4 \% \mathrm{~min}(2 \theta)$ and a diffraction angle of $5-85^{\circ}(2 \theta)$.

Scanning electron microscopy (SEM) tests: In the tests, an SEM model S-3000 N was used. First, the lower soil samples (0-20 mm) with various concentrations of corrosion are placed at $105^{\circ} \mathrm{C}$ and dried until the quality is constant to prevent the moisture in the soil samples from affecting the display of scanning images. Then, the soil with a size of about $1 \mathrm{~cm} \times 1 \mathrm{~cm} \times 1 \mathrm{~cm}$ is selected and placed in the vacuum. Finally, the magnification of the SEM is adjusted to 2,000 times. Scanning photographs are taken and images analysis is performed.

\section{RESULTS AND DISCUSSION}

Permeability characteristics: The hydraulic conductivity curves of different concentrations of leachate corrosion remoulded silty clay under different back pressures are shown in Figs. 1-3, all of which meet the requirements of the Chinese code that it should not be more than $1.0 \times 10^{-7} \mathrm{~cm} / \mathrm{s}$ (CJJ176-2012). With different landfill leachate concentrations and different back pressures, the hydraulic conductivity curve shows the phenomenon of first increasing to the peak value and then decreasing to a stable value with time. For the same concentration of the leachate, the larger the back pressure at the same time, the greater is the hydraulic con-

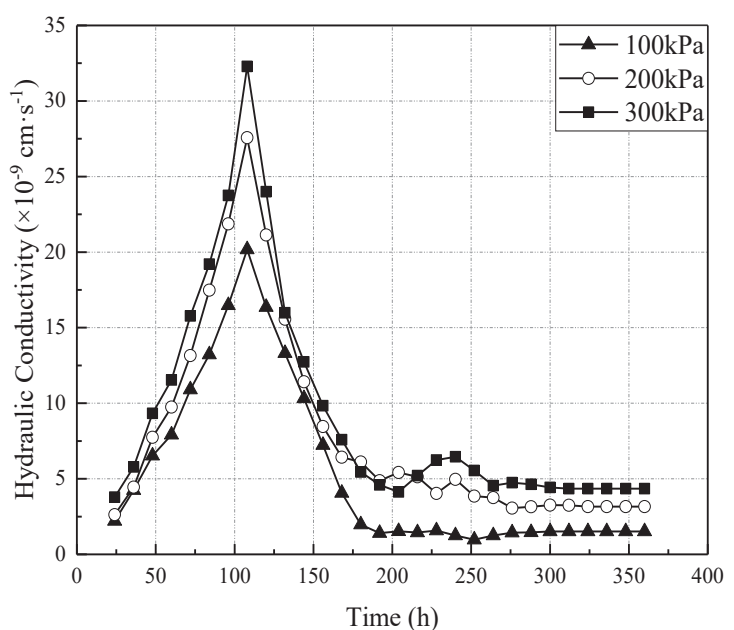

Fig. 2: Hydraulic conductivity curves of 50\% landfill leachate corrode remoulded silty clay under different back pressures. 


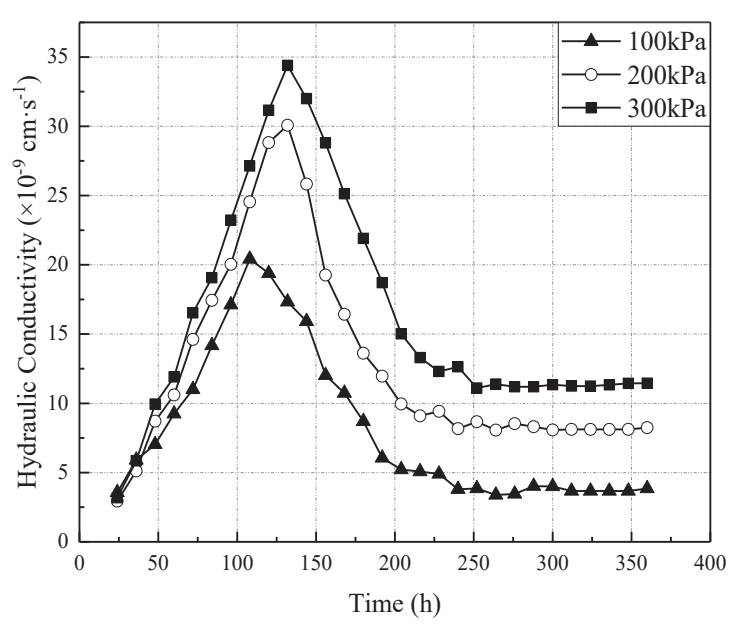

Fig. 3: Hydraulic conductivity curves of $16.7 \%$ landfill leachate corrode remoulded silty clay under different back pressures.

ductivity. The leachate concentration is different; however, the time for the hydraulic conductivity to reach the peak value is between 108 and $132 \mathrm{~h}$, and the time for reaching the stable value is between 252 and $264 \mathrm{~h}$. With the same back pressure at different concentrations, the more dilute the concentration, the longer is the increase in the time of hydraulic conductivity and shorter is the time to reach the stable value; the peak value and stable value are also higher.

When the concentration is $100 \%, 50 \%$ and $16.7 \%$, the peak value and stable value of hydraulic conductivity are respectively in the range of $19.54-20.42 \times 10^{-9} \mathrm{~cm} / \mathrm{s}$ and $0.78-3.67 \times 10^{-9} \mathrm{~cm} / \mathrm{s}$ under the action of $100 \mathrm{kPa}$ back pressure; under the action of $200 \mathrm{kPa}$ back pressure, the peak value and stable value of hydraulic conductivity are in the range of 25.36-30.07 $\times 10^{-9} \mathrm{~cm} / \mathrm{s}$ and $1.47-8.11 \times 10^{-9} \mathrm{~cm} / \mathrm{s}$, respectively; under $300 \mathrm{kPa}$ back pressure, the peak value and stable value of hydraulic conductivity is respectively in the range of $27.14-32.29 \times 10^{-9} \mathrm{~cm} / \mathrm{s}$ and $2.29-11.29 \times 10^{-9} \mathrm{~cm} / \mathrm{s}$.

The hydraulic conductivity curves show an upward trend at first, which may be explained by the fact that the sample is not completely saturated when the vacuum saturation procedure is adopted, and the hydraulic conductivity is related to the saturation. When the test is started, the bubble and the soil particles move relatively slowly, and the liquid flows around the soil particles through the bubble (Liang \& Liu 2012). Therefore, when the soil column is initially pressurized, the leachate can quickly pass through the soil sample, and the hydraulic conductivity curves show an upward tendency. After $100 \mathrm{~h}$, there is almost no air in the soil column, and it is almost completely saturated. The applied cell pressure consolidates the soil column. Simultaneously, the effective pores of the soil column are gradually reduced

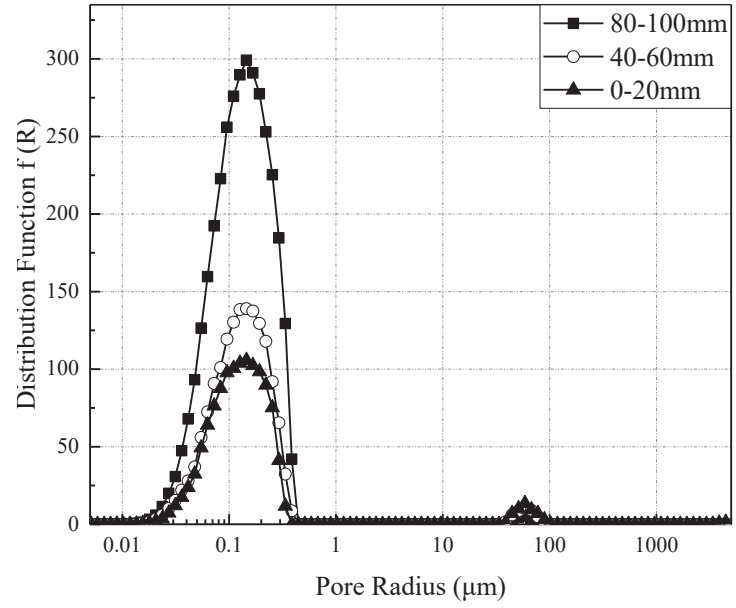

Fig. 4: Pore distribution curve of remoulded silty clay corroded by $100 \%$ landfill leachate under $100 \mathrm{kPa}$ back pressure.

by the leachate. Anaerobic microorganisms metabolize inside the soil sample to form biofilms and inorganic precipitates. Thus, this increases the permeability difficulty and decreases the hydraulic conductivity curve (Zhang et al. 2012).

Pore distribution: The pore distribution of the remoulded silty clay can be obtained according to the $T_{2}$ distribution curve of the saturated soil samples. As showing in Figs. 4-6, under the different back pressures, the pore distribution curves of each layer of remoulded silty clay after being corroded by the leachate of different concentrations have two peaks, according to International Union of Pure and Applied Chemistry (IUPAC) standard, which are mainly distributed in the range of 0.01-1.03 $\mu \mathrm{m}$ (peak 1) and 14.55-89.30 $\mu \mathrm{m}$ (peak 2 ). This indicates that the pore distribution characteristics of each layer of remoulded silty clay are macropores. Under the $100 \mathrm{kPa}$ back pressure, the total pore volume distribution of remoulded silty clay corroded by $100 \%$ leachate is 24.48 $\%$ less than that of $50 \%$ leachate corrosion, and the total pore volume distribution of $50 \%$ leachate and $100 \mathrm{kPa}$ back pressure is $34.65 \%$ less than that of $16.7 \%$ leachate and 300 $\mathrm{kPa}$ back pressure. This shows that increasing the landfill leachate concentration and reducing back pressure can reduce the overall pore volume distribution and the development effect of the overall pore structure.

Under the same back pressure, the pore volume of the bound water corresponding to peak 1 increases gradually and the pore volume of the free water corresponding to peak 2 decreases gradually in the remoulded silty clay layer from the bottom to the top with the same concentration. Under 100 $\mathrm{kPa}$ back pressure, when the landfill leachate concentration is $100 \%$ and $50 \%$, the pore volume distribution of the bound water in the remoulded silty clay from the bottom to the top 
increases by $220.92 \%$ and $107.60 \%$, respectively, and the pore volume distribution of the free water decreases by 68.90 $\%$ and $71.46 \%$, respectively.

When the landfill leachate concentration is $16.7 \%$, the pore volume distribution of bound water increases by 85.00 $\%$ and that of free water decreases by $80.21 \%$ under 300 $\mathrm{kPa}$ back pressure. Therefore, the volume distribution of bound water pores in the lower soil sample is less than that in the upper layer, and the volume distribution of free water pores is more than that in the upper layer. This is due to the infiltration process of the landfill leachate from the bottom to the top. On the one hand, the lower soil sample first passes through the landfill leachate, and the corrosion effect of internal pores in the lower layer is more serious than that in the upper layer, resulting in more free water pores in the lower layer than that in the upper layer. On the other hand, the activities of organic pollutants and anaerobic microorganisms in landfill leachate will first block the bound water pores in the lower layer, resulting in a decrease in the bound water pores in the lower layer, which also explains the phenomenon that the hydraulic conductivity curve increases first and then decreases from the microscopic pore distribution.

Mineral composition and microstructure: To explore the difference in the mineral composition and microstructure of remoulded silty clay after being corroded by the leachate of different concentrations, the NMR test results show that the pore changes in the lower layer of the remoulded silty clay are the most obvious under the corrosion of landfill leachate. Therefore, it is considered to select a representative lower layer remoulded silty clay for XRD and SEM tests, and the XRD curves obtained

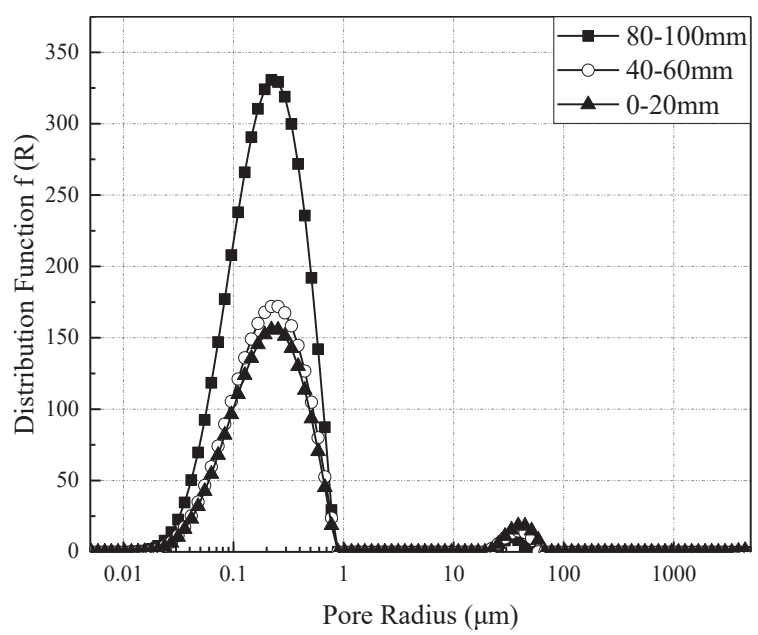

Fig. 5: Pore distribution curve of remoulded silty clay corroded by $50 \%$ landfill leachate under $100 \mathrm{kPa}$ back pressure. are shown in Fig. 7; the mineral composition changes are illustrated in Fig. 8; and the SEM scanning images of 2000 times are shown in Fig. 9.

The main mineral composition of the lower remoulded silty clay corroded by the leachate of different concentrations is similar, which comprises quartz, montmorillonite, kaolinite, albite, muscovite and illite. Before and after the leachate of different concentrations was corroded, the content of quartz did not change, which accounts for 23.41-23.97\%. When the leachate concentration is $100 \%$, the content of each mineral component decreases or increases most obviously. The contents of montmorillonite, muscovite, and illite decrease by $33.52 \%, 23.57 \%$, and $63.51 \%$, respectively, while those of kaolinite and albite increase by $283.40 \%$ and $188.64 \%$, respectively. This is because the soil sample comes from the near-surface soil, and the montmorillonite is formed in an alkaline environment, with strong adsorption capacity and cation exchange capacity. When the $\mathrm{pH}$ value of the remoulded silty clay is 5.5 and the $\mathrm{pH}$ value of landfill leachate is 6.1 , the permeability test is in a weak acidic environment, the montmorillonite content is reduced, and illite also releases $\mathrm{K}^{+}$ions into the solution resulting in a decrease in content (Tucker 1964); aluminosilicate gradually converts into kaolinite in an acidic environment. The $\mathrm{K}^{+}$migration generated by the dissolution of aluminosilicates such as feldspar is faster than that generated by dissolution, and it cannot reach the $\mathrm{K}^{+}$concentration value required to generate illite. The acidic solution provided by flexible-wall triaxial permeability tests is more favourable for the dissolution of associated kaolinite by aluminosilicates, and kaolinite has a relatively weak adhesion. The migration will occur during the infiltration process to block the channels connected be-

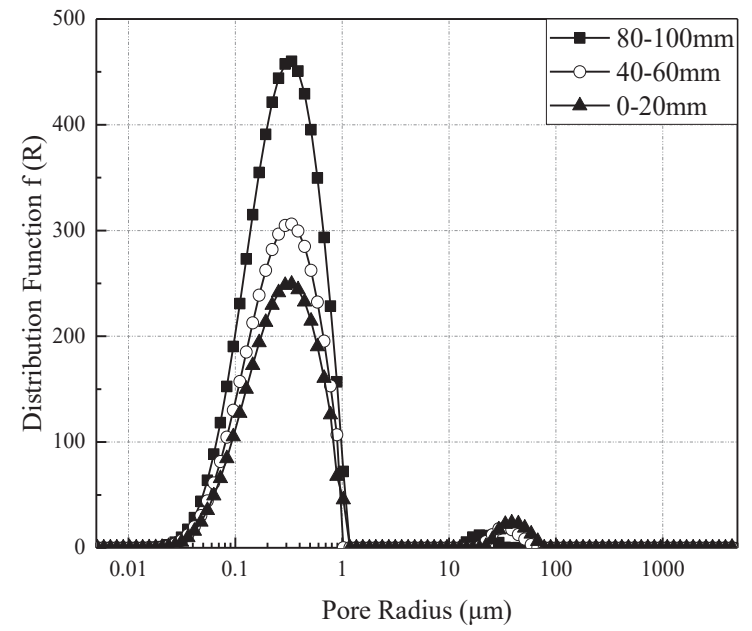

Fig. 6: Pore distribution curve of remoulded silty clay corroded by $16.7 \%$ landfill leachate under $300 \mathrm{kPa}$ back pressure. 


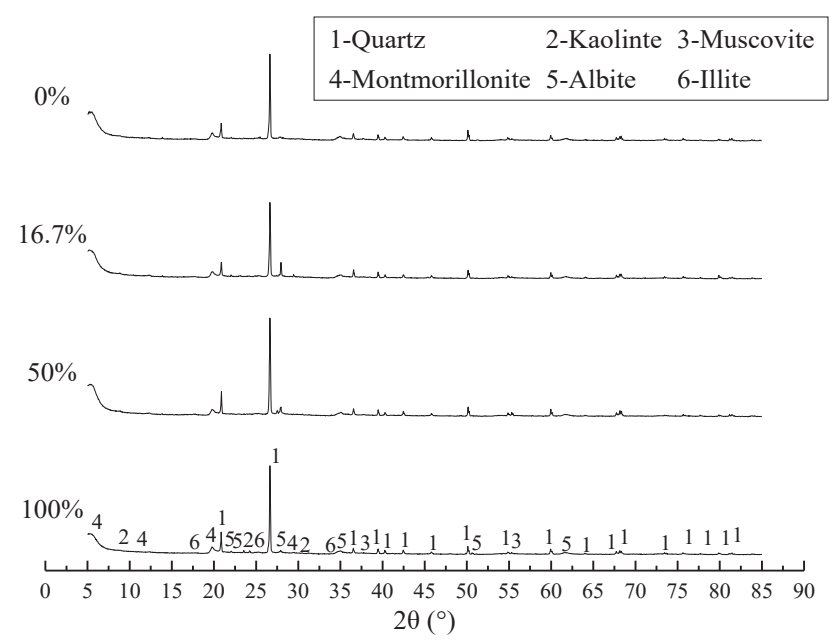

Fig. 7: XRD curves of lower remoulded silty clay corroded by different concentrations of landfill leachate.

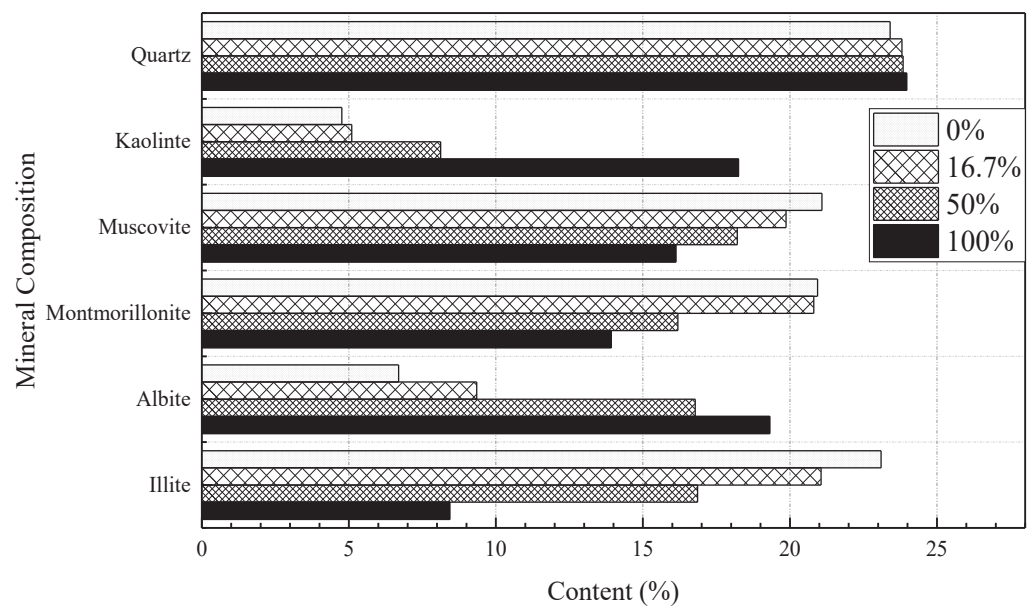

Fig. 8: Mineral composition changes in lower remoulded silty clay corroded by landfill leachate of different concentrations.

tween pores, which will lead to a decrease in the hydraulic conductivity (Jin et al. 2018).

Lower remoulded silty clay originally had irregular lamellar structure after being corroded by the landfill leachate of different concentrations. It showed irregular honeycomb and structural aggregates. According to XRD and SEM test results, the formation of aggregates in the SEM images is a product of the cementation of organic pollutants in the landfill leachate and soil particles, in the form of edge-toface combination. With an increase in the infiltration time, the macropores in remoulded silty clay gradually change into micropores and the apparent void ratio gradually decreases, which can well explain the phenomenon that the hydraulic conductivity curve shows a gradual decreasing trend. The higher the concentration of landfill leachate, the more intense is the corrosion of the remoulded silty clay. The phenomenon of cementation and agglomeration is obvious. The soil particles aggregate tightly, and the number of loose micro-particles reduces. The irregular honeycomb is obvious in SEM images, and the hydraulic conductivity decreases.

\section{CONCLUSIONS}

To study the permeability characteristics and microstructure changes of remoulded silty clay caused by landfill leachate corrosion, this paper analysed the permeability characteristics of remoulded silty clay based on flexible-wall triaxial permeability tests. Based on NMR, XRD, and SEM tests, pore distribution, mineral composition, and microstructure changes of remoulded silty clay were studied, and the following conclusions were drawn: 


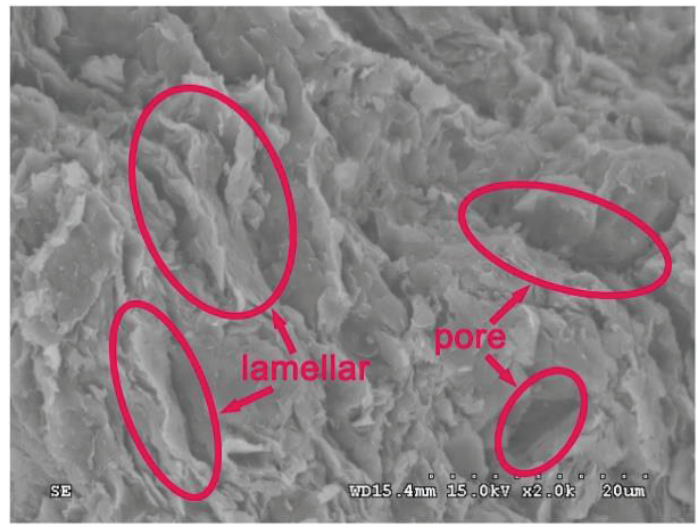

(a) $0 \%$

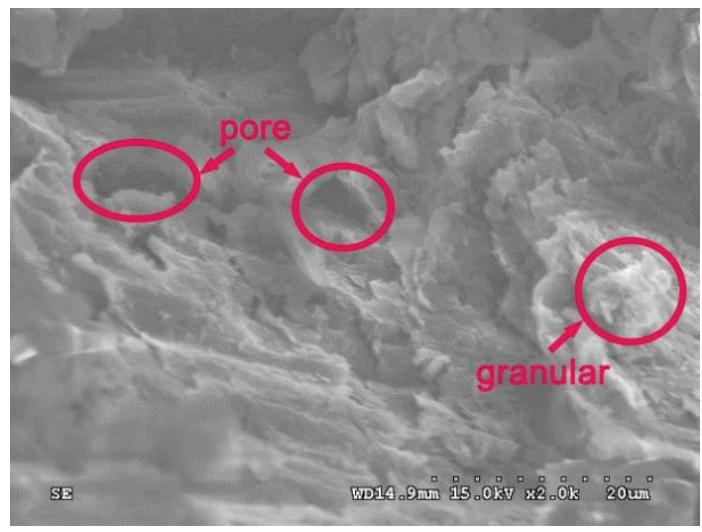

(c) $50 \%$

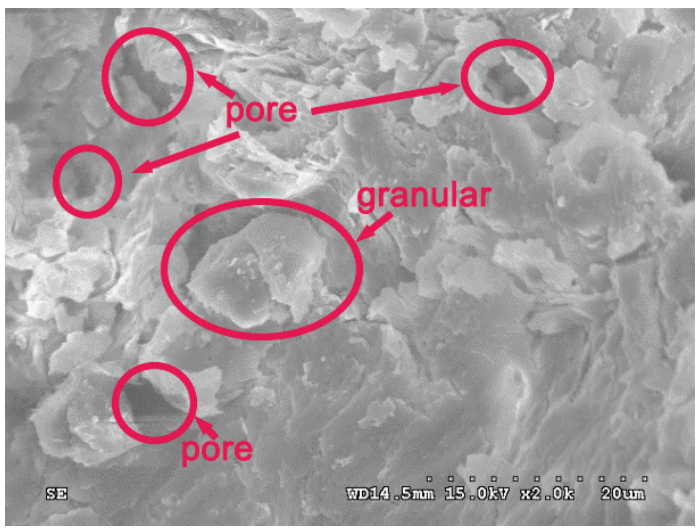

(b) $16.7 \%$

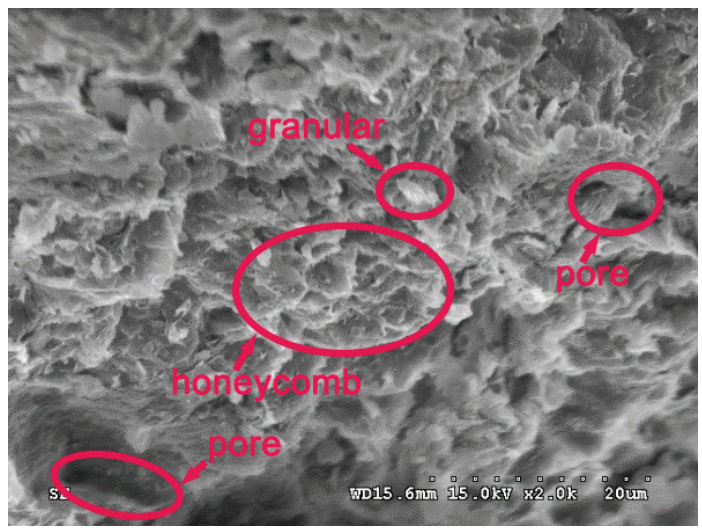

(d) $100 \%$

Fig. 9: SEM images (magnified 2000 times) of lower remoulded silty clay corroded by different concentrations of landfill leachate.

1. The saturated hydraulic conductivity of remoulded silty clay measured by flexible-wall triaxial permeability tests is not more than $1.0 \times 10^{-7} \mathrm{~cm} / \mathrm{s}$, which shows the phenomenon of increasing the peak value and then decreasing it to a stable value. The value of the hydraulic conductivity is related to the back pressure and the concentration of the landfill leachate. The larger the back pressure and the smaller the concentration, the larger is the value of hydraulic conductivity.

2. The pore size of the remoulded silty clay corroded by the leachate is distributed in the range of 0.01-1.03 $\mu \mathrm{m}$ and $14.55-89.30 \mu \mathrm{m}$. The pore distribution is macropores, and the pore volume of the bound water in the remoulded silty clay increases gradually from the bottom to the top, while the pore volume of the free water decreases slightly. The concentration of the landfill leachate in- creases and the back pressure reduces, and the overall pore volume distribution decreases.

3. The main mineral composition of the lower remoulded silty clay after the leachate of different concentrations is basically unchanged, with quartz accounting for the largest percentage, and the content remains unchanged before and after corrosion. When the leachate concentration is $100 \%$, the change of each mineral composition is the most obvious, with the contents of montmorillonite, muscovite, and illite decreasing while kaolinite and albite increasing. During the process that the landfill leachate corrodes the remoulded silty clay, while the mineral composition changes, the soil particles will be cemented into irregular aggregates, the leachate concentration increases, the aggregates become more compact, and the hydraulic conductivity gradually decreases. 


\section{ACKNOWLEDGEMENTS}

This study was financially supported by the "National Natural Science Foundation of China (11672216)".

\section{REFERENCES}

ASTM D5084 (American Society for Testing and materials) 2010. Standard test methods for measurement of hydraulic conductivity of saturated porous materials using a flexible wall permeameter. Annual Book of ASTM Standards.

CJJ176 2012. Ministry of Building and Construction, P.R. China 2012. Technical code for geotechnical engineering of municipal solid waste sanitary landfill (CJJ176-2012), Beijing, (in Chinese).

Dontsova, K.M. and Norton, L.D. 2015. Clay dispersion, infiltration, and erosion as influenced by exchangeable $\mathrm{Ca}$ and $\mathrm{Mg}$. Soil Science, 167(3): 184-193.

Gu, Z.W., Sun, B.N. and Dong, Y.N. 2003. Testing study of permeability of the original clay, recomposed clay and improved clay with stabilizer zdyt-1. Chinese Journal of Rock Mechanics and Engineering, 22(3): 505-508.

Jin, P.P., Ou, C.H., Ma, Z.G., Li, D. Ren, Y.J. and Zhao, Y.F. 2018. Evolution of montmorillonite and its related clay minerals and their effects on shale gas development. Geophysical Prospecting for Petroleum, 57(3): 344-355.

Kjeldsen, P., Barlaz, M.A., Rooker, A.P., Baun, A., Ledin, A. and Christensen, T.H. 2002. Present and long-term composition of MSW landfill leachate: a review. Critical Reviews in Environmental Science and Technology, 32(4): 297-336.

Li, H.B., Zhu, J.Y. and Guo, H.K. 2008. Methods for calculating pore radius distribution in rock from NMR T2 spectra. Chinese Journal of Magnetic Resonance, 25(2): 273-280.

Li, J.S., Xue, Q., Wang, P. and Liu, L. 2013. Influence of leachate pollution on mechanical properties of compacted clay: A case study on behaviors and mechanisms. Engineering Geology, 167: 128-133.

Liang, A.M. and Liu, X. 2012. Testing study on permeability characteristics of unsaturated soil. Journal of Jinggangshan University (Natural Science), 33(2): 76-79, 87.
Met, İ. and Akgün, H. 2015. Geotechnical evaluation of Ankara clay as a compacted clay liner. Environmental Earth Sciences, 74(4): 2991-3006.

Razakamanantsoa, A. R. and Djeran-Maigre, I. 2016. Long term chemo-hydro-mechanical behavior of compacted soil bentonite polymer complex submitted to synthetic leachate. Waste Management, 53: 92-104.

Roth, C. H. and Pavan, M. A. 1991. Effects of lime and gypsum on clay dispersion and infiltration in samples of a Brazilian Oxisol. Geoderma, 48(3-4): 351-361.

Safari, E. and Valizadeh, R. 2017. Analysis of biological clogging potential in a simulated compacted clay liner subjected to high-strength leachate infiltration. International Journal of Environmental Science and Technology, 15(5): 1029-1038.

SL237 1999. Ministry of Water Resources, P.R. China 1999. Specification of soil test (SL237-1999), Beijing, (in Chinese).

SY/T 5163-2010. National Energy Administration, P.R. China 2010. Analysis method for clay minerals and ordinary non-clay minerals in sedimentary rocks by the X-ray diffraction (SY/T 5163-2010), Beijing, (in Chinese).

Tian, H., Wei, C., Wei, H., Yan, R. and Chen, P. 2013. An NMR-based analysis of soil-water characteristics. Applied Magnetic Resonance, 45(1): 49-61.

Tucker, BM. 1964. The solubility of potassium from soil illites. I. the dependence of solubility on pH. Soil Research, 2(1): 56-66.

Varank, G., Demir, A., Top, S., Sekman, E., Akkaya, E., Yetilmezsoy, K. and Bilgili, M. S. 2011. Migration behavior of landfill leachate contaminants through alternative composite liners. Science of the Total Environment, 409(17): 3183-3196.

Zhan, L.T., Xu, H., Chen, Y.M., Lü, F., Lan, J.W., Shao, L.M., Lin, W.A. and He, P.J. 2017. Biochemical, hydrological and mechanical behaviors of high food waste content MSW landfill: preliminary findings from a large-scale experiment. Waste Management, 63: 27-40.

Zhang, H.Y., Yang, B., Gao, Q.Q. and Zhang, G.W. 2012. Permeability and heavy metal retardation of sewage sludge barrier. Rock and Soil Mechanics, 33(10): 2910-2916.

Zhao, Y., Xue, Q., Huang, F., Hu, X. and Li, J. 2016. Experimental study on the microstructure and mechanical behaviors of leachate-polluted compacted clay. Environmental Earth Sciences, 75(12): 1006.

Zhou, C., Fan, X., Ning, Z., Li, P., Liu, C., Yang, P., Liu, Y., Shi, Z. and Li, Y. 2015. Reducing riverbed infiltration using mixtures of sodium bentonite and clay. Environmental Earth Sciences, 74(4): 3089-3098. 